medRxiv preprint doi: https://doi.org/10.1101/2021.10.23.21265419; this version posted October 26, 2021. The copyright holder for this preprint (which was not certified by peer review) is the author/funder, who has granted medRxiv a license to display the preprint in perpetuity.

It is made available under a CC-BY-NC-ND 4.0 International license .

\title{
Leptospira infection in rural areas of Urabá region, Colombia: a prospective study
}

\author{
Juan C. Quintero-Vélez ${ }^{1,2,3,4}$, Juan D. Rodas $\mathrm{G}^{1}$, Carlos Rojas A4 , Albert I. Ko $^{3,5}$, Elsio A. \\ Wunder $\mathrm{Jr}^{3,5}$
}

${ }^{1}$ Grupo de Investigación Ciencias Veterinarias Centauro, Universidad de Antioquia, Medellín, Colombia.

${ }^{2}$ Grupo de Investigación Microbiología Básica y Aplicada, Universidad de Antioquia, Medellín, Colombia.

${ }^{3}$ Department of Epidemiology of Microbial Diseases, Yale School of Public Health, New Haven, CT, 06510; United States.

${ }^{4}$ Grupo de Epidemiología, Universidad de Antioquia, Medellín, Colombia.

${ }^{5}$ Gonçalo Moniz Institute, Oswaldo Cruz Foundation; Brazilian Ministry of Health; Salvador, BA, 40296-710; Brazil.

\section{ABSTRACT}

The objective of this study was to analyze the eco-epidemiological aspects of Leptospira seroprevalence and seroincidence, and its associated factors in two municipalities of northwest Colombia. A prospective study was performed in rural areas of Urabá, Antioquia, Colombia. The study enrolled 597 people between November-2015 and January-2016, of which 274 people were followed up one year later. Serologic testing was performed by a microscopic agglutination. The outcomes were seroprevalent and seroincident cases, and the main exposure was an outdoor occupation. A binary and mixed-effect multinomial logistic regression model was used to estimate factors associated with seroprevalent or seroincident cases of Leptospira infection. The overall Leptospira seroprevalence was $27.81 \%$ (95\%CI:23.62-32.49) and the overall cumulative seroincidence for Leptospira was 14.60\% (95\%CI:10.33-20.23).

Multivariable analysis showed that factors associated with L. interrogans serogroups seropositivity were outdoor occupation, male gender, older age, the presence of dirt soil in the household, and the presence of piglets and opossums. It also showed that factors associated with other Leptospira species serogroups were the presence of pit latrines and of turkeys. In addition, the multivariable model of seroincident cases of $L$. interrogans serogroups evidenced outdoor occupations, the presence of rats, and corn cultivation as risk factors. Likewise, the multivariable model for seroincident cases of other Leptospira species showed that the presence of hunting canines and cassava cultivation were risk factors. We found specific factors associated with the 
medRxiv preprint doi: https://doi.org/10.1101/2021.10.23.21265419; this version posted October 26, 2021. The copyright holder for this preprint (which was not certified by peer review) is the author/funder, who has granted medRxiv a license to display the preprint in perpetuity. It is made available under a CC-BY-NC-ND 4.0 International license.

36 transmission of Leptospira serogroups contribute to the understanding of the epidemiology of

37 Leptospira infection in rural areas of Urabá, Colombia.

Keywords

Leptospira, leptospirosis, Colombia, Urabá, seroprevalence, seroincidence

\section{AUTHOR SUMMARY}

43 More than one million cases of leptospirosis occur each year, and about 60,000 people die of the

44 disease worldwide. Leptospirosis is a zoonotic bacterial disease imparting its heaviest burden on

45 resource-poor populations. It is also a major cause of economic loss in farm animals causing fetal

46 infections, abortion, stillbirths, infertility, and increased culling rate. Leptospires also

47 contaminate surface waters and survive in mud and moist soils, facilitating transmission among

48 hosts. This complex cycle of transmission makes the disease a suitable model for a one-health approach. This is a prospective study conducted in rural areas of Colombia aimed at identifying the factors associated with seroprevalent and seroincident Leptospira cases. In addition, the

51 results showed that the presence of synanthropic and domestic animals, the characteristics of

52 household materials, and individual variables were factors associated with Leptospira

53 seropositivity. This study clarifies the epidemiology of Leptospira infection and could improve

54 the surveillance program in Colombia, especially in rural areas.

\section{INTRODUCTION}

Leptospirosis is a zoonotic bacterial disease that burdens resource-poor populations the most ${ }^{1}$.

The disease is caused by pathogenic species of the genus Leptospira, which comprises 64 species

2. The incidence rate of leptospirosis worldwide ranges from 0.10 to 975 cases per 100,000 population, and new cases are more frequent in tropical countries ${ }^{3,4}$. Environmental (rainfall, seasons, and erosions) and ecological factors, such as the relationship between human-domestic animals and wild mammals, and socio-cultural characteristics, including outdoor occupations and practices, increase the number of leptospirosis cases ${ }^{5-8}$.

67 Leptospirosis has been a mandatory notifiable disease in Colombia since $2007{ }^{9}$, with a reported 68 case fatality rate of between $1.40 \%$ and $2.24 \%$ during the period 2016-2018 ${ }^{10-12}$. During the same period, 1,885 cases of the disease were confirmed; a significant proportion $(18.30 \%)$ of 
medRxiv preprint doi: https://doi.org/10.1101/2021.10.23.21265419; this version posted October 26, 2021. The copyright holder for this preprint (which was not certified by peer review) is the author/funder, who has granted medRxiv a license to display the preprint in perpetuity. It is made available under a CC-BY-NC-ND 4.0 International license .

these cases occurred in the Department of Antioquia, especially in the municipalities of Turbo and Apartadó in the Urabá region ${ }^{10-12}$. In this region, the seroprevalence of Leptospira was estimated to be $12.50 \%$ (95\% CI 10.01-15.50) in 2007, with the highest seropositivity proportion found in Carepa (27.3\%), Necoclí, and San Pedro de Urabá (25.00\%), followed by Apartadó (14.80\%), Turbo (11.80\%), and Chigorodó $(7.50 \%)^{13}$. However, higher seropositivity was found later in Necoclí (35.60\%) in 2009, indicating a potential increase in the transmission in the region ${ }^{14}$. Among patients with febrile syndrome studied between 2007 and 2008 in Apartadó and Turbo, 31 cases $(14.1 \%)$ were diagnosed with leptospirosis, and serogroups Tarassovi and Semaranga were identified in those patients ${ }^{15}$. Moreover, studies conducted in the Urabá region have identified socio-ecological factors associated with L. interrogans exposure ${ }^{14}$.

Previous studies have shown that cases of leptospirosis are occurring in the Urabá region ${ }^{16}$. The Urabá region, especially rural areas, has conditions favoring the circulation of Leptospira such as the presence of synanthropic rodents in households, the presence of wild animals in peridomiciliary areas, keeping domestic animals under unsanitary conditions, occupations with a potential risk of infection (agriculture), and inappropriate water supply and sewage disposal methods ${ }^{17-19}$. Besides, the failure to report cases of leptospirosis in Urabá has been related to poor recognition of areas and people at risk of presenting the disease ${ }^{16,20}$. However, additional analytical studies aimed identifying factors associated with the seroprevalence and seroincidence of infection with different Leptospira serogroups have rarely been conducted in Colombia.

The overall objective of this study was to analyze the eco-epidemiological aspects of Leptospira seroprevalence and the incidence and associated risk factors of infection in two municipalities of northwest Colombia. Through a prospective study analysis, we were able to identify socioecological factors (human, wild, and domestic animal relationships, age, occupation, land use, and household characteristics) related to Leptospira seropositivity in humans and determine the seroincidence of Leptospira infection among individuals living in those areas. Our study provides a better understanding of the epidemiology of Leptospira infection in the region that can be expanded to similar areas in Colombia and throughout the world. It can also help guide public health measures to help intervention strategies and reduce the transmission of leptospirosis.

\section{MATERIALS AND METHODS}


medRxiv preprint doi: https://doi.org/10.1101/2021.10.23.21265419; this version posted October 26, 2021. The copyright holder for this preprint (which was not certified by peer review) is the author/funder, who has granted medRxiv a license to display the preprint in perpetuity. It is made available under a CC-BY-NC-ND 4.0 International license .

\section{Study design}

A prospective study was conducted in two rural areas of Urabá, Colombia, in the localities of Alto de Mulatos, Turbo (808'12.5"N 76³3'01.7"W), and Las Changas, Necoclí (8³2'52.5"N 76³4'23.7"W) (Figure 1) located 356 and 418 km from Medellín city, the capital city of the Department of Antioquia. Between November 2015 and January 2016, individuals of both genders residing in the study area who agreed to sign the informed consent were included in the

111 baseline study (T0). People were excluded if they planned to move out from the study area

112 within the following year and if they were suspected of being affiliated with illegal armed 113 groups (this information was contributed by a research team that inhabited the study region). The 114 same participants were followed up 12 months later, between November 2016 and January 2017 115 (T12).

\section{Sampling design}

118 Nine hamlets, five in Alto de Mulatos and four in Las Changas, were selected according to the 119 ecological factors associated with infectious tropical diseases (the presence of wild mammals, 120 the characteristics of the water supplies, and the presence of mosquitos and ticks, among others), 121 the number of households, the presence of illegal armed groups, and the distance to urban centers 122 (because of study logistics). This study constitutes a secondary prospective analysis of the main 123 study designed to estimate the seroprevalence against agents of the Rickettsia genus ${ }^{21}$. However, 124 the proportion of seropositivity used for sample size estimation and the sampling design allowed 125 other outcomes to be strongly and confidently evaluated. A complex random sampling was 126 carried out with households as the sample units and their inhabitants as the analysis units. Based 127 on the 461 households and 1,915 inhabitants identified in the census tract, a sample size of 208 128 households was estimated, using a 95\% level of confidence, 5\% error, and $41 \%$ expected 129 prevalence ${ }^{21}$. The sampling was proportional to the number of households in each hamlet, and a second serum sample was collected a year later from the same individuals included in the

131 baseline study.

\section{Leptospira seropositivity}

134 The research team collected blood samples from participants at baseline (T0) and the followed135 up study (T12). The serum samples were tested by microscopic agglutination test (MAT). To 136 select the antigens for sample testing, a panel of 32 Leptospira strains, representing different 137 species and serogroups, was evaluated (Table 1) using a random selection of $20 \%$ of the total 
medRxiv preprint doi: https://doi.org/10.1101/2021.10.23.21265419; this version posted October 26, 2021. The copyright holder for this preprint (which was not certified by peer review) is the author/funder, who has granted medRxiv a license to display the preprint in perpetuity. It is made available under a CC-BY-NC-ND 4.0 International license .

138 human serum samples collected at T0. After the evaluation, antigens with no agglutination results were eliminated from the panel, and a final list of 16 antigens was established to be tested with all sera for this study (Table 1). The MAT assay was performed according to Felzemburgh, et al. ${ }^{6}$. The evaluation and final screening assays were performed using dilutions of 1:50 and

142 1:100 for human samples, and a positive sample was determined when $50 \%$ or more leptospires

143 for a specific strain were agglutinated. Following the screening assay, positive samples were

144 titrated to determine the higher titer for each strain.

\section{Outcome definitions}

147 In the primary analysis, the outcome of seroprevalent cases of Leptospira infection was defined as a positive MAT titer $\geq 1: 50$ with $50 \%$ or more leptospires agglutination at baseline (T0). Also, the outcome of seroincident cases of Leptospira infection was measured by MAT seroconversion from negative to positive or by a minimum four-fold increase in titers between follow-up samples (T12 vs. T0). The serogroup that represented the highest antibody titer was defined as

152 the presumptive infecting serogroup. However, when two or more serogroups had the same titer, the sample was considered mixed serogroup seropositivity. Additionally, the seroprevalent and seroincident outcomes were categorized as seropositive to Leptospira interrogans serogroups and seropositive to other Leptospira species serogroups to perform a secondary analysis (multinomial analysis) (Table 1).

\section{Study exposures and covariates}

The main exposure was by working outdoors (farmers, ranchers, agricultural workers, day laborers, and water recollectors, among others). For the T0 study, this exposure was analyzed as a previous outdoor occupation (within the last five years) and a recent outdoor occupation (the previous year before the sample collection). For the prospective study, the outdoor occupation was evaluated based on the previous year before the sample collection.

Additionally, individual variables such as age (years), gender, ethnicity, time of residence in the year of follow-up) were evaluated as potential confounders of the association between the main exposure and the outcomes. 
medRxiv preprint doi: https://doi.org/10.1101/2021.10.23.21265419; this version posted October 26, 2021. The copyright holder for this preprint (which was not certified by peer review) is the author/funder, who has granted medRxiv a license to display the preprint in perpetuity. It is made available under a CC-BY-NC-ND 4.0 International license .

172 presence of domestic animals in intra or peridomiciliary areas (the presence of canines, felines,

173 poultry, turkeys, pigs, horses, donkeys, and mules), and the presence of synanthropic or wild

174 animals in peridomiciliary areas (the presence of rodents and opossums). Additionally,

175 covariates such as the type of roof and floor, wall materials, the characteristics of peridomiciliary

176 areas (the presence of bushes, trees, grasses, corn cultivation, cassava cultivation, and tomato

177 cultivation), household location (urban center and rural area) and household proximity (very

178 near, near, scattered, and very scattered) were analyzed. Finally, common practices among

179 family members such as forest fragmentation, deforestation, and the use of any rodent

180 elimination measures were considered as covariates.

\section{Statistical analysis}

183 The seroprevalence and cumulative seroincidence were estimated considering the number of

184 seropositive cases in the numerator and the number of people evaluated in both times (T0 and

$185 \mathrm{~T} 12)$ as a denominator. Also, the confidence intervals were adjusted by random effects of the models (hamlets) for seroprevalence and seroincidence. In addition, the seroprevalent and seroincident cases were characterized using relative and absolute frequencies for qualitative variables and median and interquartile range for quantitative variables.

To estimate risk factors for seroprevalent and seroincident cases of Leptospira infection, a mixed-effects binary logistic regression model was used (seronegative vs seropositive samples). Additionally, a multinomial analysis was conducted using a mixed-effects multinomial logistic regression model for a specific evaluation of factors associated with the outcome of seropositive against $L$. interrogans serogroups and seropositive against other Leptospira species serogroups. Moreover, both models included three levels: individuals within households, households within

197 The association between the main outcome (Leptospira seropositivity in humans) and variables at each level was evaluated (household and hamlet level). The linearity assumption was confirmed previous to the inclusion of quantitative variables in bivariate and multivariate models. Variables included in the multivariate models were those with $p<0.25$ in bivariate analysis. The multivariate analyses were performed using the stepwise method based on the

203 humans were weighted by the inverse probability of human selection in each hamlet.

204 Confounders were evaluated in multivariate models, and the model that best explained the 
medRxiv preprint doi: https://doi.org/10.1101/2021.10.23.21265419; this version posted October 26, 2021. The copyright holder for this preprint (which was not certified by peer review) is the author/funder, who has granted medRxiv a license to display the preprint in perpetuity. It is made available under a CC-BY-NC-ND 4.0 International license .

206 estimated in the cross-sectional study, and relative risks (RR) were estimated in the prospective 207 study according to Localio, $2007^{22}$. All analyses were performed in SAS 9.04.01 using PROC 208 GLIMMIX [17].

Ethics statement

211 The Committee of Ethics in Research of the University of Antioquia approved all procedures

212 carried out in the present study, and participants were enrolled according to written informed 213 consent procedures previously approved by the Committee of Ethics in Research.

\section{RESULTS}

\section{Leptospira seroprevalence and associated factors}

Binary outcome analysis

220 For the baseline study (T0), 597 individuals (255 from Alto de Mulatos and 342 from Las 221 Changas) that inhabited 246 households located in the rural areas (18\% of oversampling) were 222 enrolled. One hundred and three of them were in Alto de Mulatos and 143 in Las Changas. The sampling coverage of households and persons were $100 \%$ and 58.41\% (597/1022), respectively.

224 The overall Leptospira seroprevalence was $27.81 \%$ (166/597) (95\% CI: 23.62-32.49), and the socio-ecological characteristics showed that $42.77 \%$ (71/166) of seropositive individuals had outdoor occupations, $52.41 \%$ (87/166) identified themselves as of male gender, and the mean age

227 in years was 31.43 (IQR: 18.94-48.72). Additionally, among the seropositive individuals,

$22862.65 \%(104 / 166)$ reported a history of fever, and 79.52\% (132/166) reported inhabiting houses

229 with dirt soil floors. Regarding the presence of domestic animals in intra or peridomiciliary 230 areas, 55.42\% (92/166) of seropositive individuals reported having seen opossums in the 231 peridomiciliary, area and $26.51 \%$ (44/166) reported the presence of piglets in their household 232 (Table S1).

234 Our analysis identified outdoor occupations (OR $=1.56 ; 95 \%$ CI:1.05-2.31), the presence of a 235 dirt soil floor in the household (OR $=1.62 ; 95 \% \mathrm{CI}: 1.14-2.31)$, the presence of opossums in the 236 peridomiciliary area $(\mathrm{OR}=1.34 ; 95 \% \mathrm{CI}: 1.003-1.80)$, and the tenancy of piglets $(\mathrm{OR}=1.45$;

$23795 \% \mathrm{CI}: 1.02-2.07)$ as risk factors to seropositivity against Leptospira. Also, the age as a categorized variable $(\mathrm{OR}>15-29$ years vs $\leq 1-15$ years $=2.30 ; 95 \% \mathrm{CI}: 1.47-3.60$ and $\mathrm{OR}>46$ years vs $\leq 1-15$ 
medRxiv preprint doi: https://doi.org/10.1101/2021.10.23.21265419; this version posted October 26, 2021. The copyright holder for this preprint (which was not certified by peer review) is the author/funder, who has granted medRxiv a license to display the preprint in perpetuity. It is made available under a CC-BY-NC-ND 4.0 International license .

years $=1.95 ; 95 \% \mathrm{CI}: 1.07-3.55)$, the male gender $(\mathrm{OR}=2.01 ; 95 \% \mathrm{CI}: 1.42-2.84)$ and a history of fever $(\mathrm{OR}=1.42 ; 95 \% \mathrm{CI}: 1.05-1.91)$ were factors associated with seropositivity (Table S1).

Multinomial outcome analysis

243 According to our multinomial analysis, the seroprevalence of L. interrogans serogroups was 18.25\% (109/597) (95\% CI: 14.34-23.11), and the seroprevalence of other Leptospira serogroups was $9.56 \%$ (57/597) (95\% CI: 7.11-12.70). Among the participants seropositive to $L$. interrogans, the most frequent serogroup was Bataviae, followed by mixed serogroups and Djasiman. In addition, among the participants seropositive to other Leptospira species, the most frequent serogroup was Tarassovi, followed by Panama and Cynopteri (Figure 2).

Sociodemographic characteristics showed that $58.72 \%(64 / 109)$ of seropositive individuals against L. interrogans and 40.35\% (23/57) seropositive for other Leptospira species were male.

252 The median age of seropositive individuals was 33.23 years (IQR:19.67-49.25) and 28.42 years higher proportion of the seropositive to L. interrogans serogroups had an outdoor occupation

$255(52.29 \%, 57 / 109)$, while only $24.56 \%$ (14/57) of seropositive persons to other Leptospira species serogroups had similar occupations (Table S2).

Most of the participants that were seropositive to L. interrogans $(81.65 \%, 89 / 109)$ and other half of the seropositive individuals in both groups had indoor plumbing (49.54\% for $L$. interrogans and 54.39\% for other Leptospira species). Additionally, the presence of pit latrines in the households was $45.78 \%$ (52/109) for people with L. interrogans seropositivity and $47.37 \%$ (27/57) for other Leptospira species seropositivity (Table S2).

Regarding the presence of domestic, synanthropic, and wild animals, 60.55\% (66/109) of people with seropositivity against $L$. interrogans and $45.61 \%(26 / 57)$ of people with seropositivity against other Leptospira species reported the presence of opossums in the peridomiciliary area. The presence of rats in intra and peridomiciliary areas was 84.40\% (92/109) and 85.96\% (49/57) in people seropositive against L. interrogans and other Leptospira species, respectively. In addition, $1.83 \%$ (2/109) of people seropositive to L. interrogans and 7.02\% (4/57) of people seropositive to other Leptospira species had hunting canines (Table S2). 
medRxiv preprint doi: https://doi.org/10.1101/2021.10.23.21265419; this version posted October 26, 2021. The copyright holder for this preprint (which was not certified by peer review) is the author/funder, who has granted medRxiv a license to display the preprint in perpetuity. It is made available under a CC-BY-NC-ND 4.0 International license .

273 The multivariable multinomial analysis showed that occupations such as ranchers, daily laborers,

274 farmers, and agricultural (and similar) workers were a risk factor for the outcome of $L$.

275 interrogans serogroups seropositivity $(\mathrm{OR}=2.06$; $95 \% \mathrm{CI}: 1.31-3.26)$. In addition, the male

276 gender $(\mathrm{OR}=2.34 ; 95 \% \mathrm{CI}: 1.55-3.53)$ and older age $(\mathrm{OR}>15-29$ years vs $\leq 1-15$ years $=2.52 ; 95 \%$

277 CI:1.44-4.41 and OR > 46 years vs $\leq 1-15$ yeras $=1.95 ; 95 \%$ CI:1.07-3.55), the presence of dirt soil in

278 the household $(\mathrm{OR}=1.87 ; 95 \% \mathrm{CI}: 1.21-2.89)$, and the presence of piglets $(\mathrm{OR}=1.66 ; 95 \%$

279 CI:1.11-2.49) and opossums (OR = 1.58; 95\% CI:1.11-2.23) in the peridomiciliary area were

280 factors associated with L. interrogans serogroups seropositivity. Besides, the multivariable

281 model for the outcome of seropositivity to other Leptospira species serogroups adjusted by

282 occupation, gender, and age showed that the presence of pit latrines (OR $=2.34$; 95\% CI:1.27-

283 4.32) and turkeys as companionship (OR =4.99; 95\% CI:2.03-12.30) were risk factors (Table

$2842)$.

285

286

Leptospira seroincidence and associated factors

287

288

Binary outcome analysis

289 In the follow-up study, 274 participants were enrolled at 12 months (T12), and 120 and 154

290 people were followed up in Alto de Mulatos and Las Changas, respectively. In Table S3, the

291 characteristics of the people included in the study and lost to the follow-up in both areas are

292 shown. The overall cumulative seroincidence of Leptospira was 14.60\% (40/274) (95\% CI:

$29310.33-20.23), 35.00 \%$ (14/40) of the seroincident cases had an outdoor occupation, and 27.50\%

294 (11/40) were identified as male. In addition, the median age in years of seroincident cases was

29540.30 (IQR: 20.46-55.34), and 80.00\% (32/40) were inhabitants of a household with a dirt soil

296 floor. Furthermore, among the seroincident cases, 5.00\% (2/40), 2.99\% (3/40), and 85.00\%

297 (34/49) of the seroincident cases disclosed the presence of corn cultivation around the household

298 and hunting canines and rats in the intra or peridomiciliary areas, respectively (Table S4).

299 According to risk factors associated with seroincident cases of Leptospira infection, an outdoor

300 occupation in the last year $(\mathrm{RR}=2.66 ; 95 \% \mathrm{CI}: 1.46-4.68)$, a dirt soil floor in the household (RR

$301=1.77 ; 95 \% \mathrm{CI}: 1.01-3.06)$, the presence of corn cultivation in the peridomiciliary area $(\mathrm{RR}=$

$3028.33 .74 ; 95 \% \mathrm{CI}: 2.21-19.65)$, the presence of hunting canines (RR $=5.16 ; 95 \% \mathrm{CI}: 1.83-10.74)$,

303 and rat infestation $(\mathrm{RR}=2.00 ; 95 \% \mathrm{CI}: 1.03-3.76)$ in the intra or peridomiciliary area were

304 identified (Table S4).

305 
medRxiv preprint doi: https://doi.org/10.1101/2021.10.23.21265419; this version posted October 26, 2021. The copyright holder for this preprint (which was not certified by peer review) is the author/funder, who has granted medRxiv a license to display the preprint in perpetuity. It is made available under a CC-BY-NC-ND 4.0 International license .

307 The multinomial analysis regarding serogroups showed that the seroincidence for L. interrogans serogroups and other Leptospira species serogroups was 8.39\% (23/274) (95\% CI: 5.25-13.15) and $6.20 \%$ (17/274) (95\% CI: 3.38-10.93), respectively. Seroincident cases of L. interrogans and other Leptospira serogroups were male in $30.43 \%$ (7/23) and 23.53\% (4/17) of cases,

311 respectively. Also, 39.13\% (9/23) of seroincident cases of L. interrogans serogroups and 29.41\%

312 (5/17) of seroincident cases of other Leptospira serogroups had had outdoor occupations in the

313 previous year. The median age for the seroincident cases was 47.46 years (IQR: 24.76-58.42)

314 and 29.99 years (18.19-49.28) for L. interrogans serogroups and other Leptospira species

315 serogroups, respectively. Only one person in the group of L. interrogans reported a history of

316 fever in the year of follow-up (Table S5).

In addition, for the characteristics of the peridomiciliary area, 8.70\% (2/23) of seroincident cases by L. interrogans serogroups reported corn cultivations around their houses. Cassava cultivations were also reported in the peridomiciliary area of seroincident cases for L. interrogans (13.04\%, 3/23) and other Leptospira serogroups (17.65\%, 3/17). Additionally, households of seroincident cases for both outcomes had a high frequency of rat infestation with $91.30 \%(21 / 23)$ for $L$. interrogans and 76.47\% (13/17) for other Leptospira species. Only the seroincident cases for other Leptospira species serogroups reported hunting canines $(17.65 \%, 3 / 17)$ (Table S5).

The multivariable model evidenced outdoor occupations in the last year $(\mathrm{RR}=2.93 ; 95 \%$ the households $(\mathrm{RR}=22.74 ; 95 \% \mathrm{CI}: 5.75-51.74)$ as risk factors for the seroincident cases of $L$. interrogans serogroups. Besides, the age in years (as a quantitative variable) was a risk marker $(\mathrm{RR}=1.02 ; 95 \% \mathrm{CI}: 1.01-1.04)$, and male gender was a protector marker $(\mathrm{RR}=0.34 ; 95 \%$ CI:0.15-0.80) for the seroincident cases of L. interrogans serogroups (Table 3). Likewise, the multivariable model for seroincident cases of other Leptospira species adjusted by occupation, age, and gender, showed that the presence of hunting canines ( $\mathrm{RR}=6.17$; 95\% CI:2.72-10.99)

Among L. interrogans seroincident cases, the most frequent serogroup seropositivity was against Bataviae, followed by Djasiman and mix serogroups (Figure 3). Of note, 100\% of seroincident cases of Djasiman, Icterohaemorrhagiae, and Autumnalis serogroups were exposed to rodents in their households, and $88.88 \%$ of seroincident cases to Bataviae serogroup had the same exposure 
medRxiv preprint doi: https://doi.org/10.1101/2021.10.23.21265419; this version posted October 26, 2021. The copyright holder for this preprint (which was not certified by peer review) is the author/funder, who has granted medRxiv a license to display the preprint in perpetuity. It is made available under a CC-BY-NC-ND 4.0 International license .

341 seropositivity was against Tarassovi, followed by Panama (Figure 3). Furthermore, 50\% (3/6)

342 and $60 \%(3 / 5)$ of seroincident cases to Tarassovi and Panama serogroups had pigs and opossums 343 around their households, respectively.

\section{DISCUSSION}

Leptospirosis is a zoonotic disease with mandatory notification to the National Surveillance System in Public Health in Colombia since 2007. However, the program fails to detect active cases of leptospirosis in rural areas due to the low access to diagnostic tests and the lack of medical presumption ${ }^{20}$. Thus, conducting prospective studies to analyze and detect potential areas at risk of transmission of tropical diseases, as well as estimating risk and protective factors

352 for subsequent interventions, are becoming increasingly necessary. The Urabá region in the

353 Department of Antioquia, Colombia, is considered a potential endemic region for tropical

354 diseases such as malaria, leishmaniasis, dengue viruses, leptospirosis, and rickettsiosis, among others $15,23,24$. Therefore, analyzing seropositivity outcomes for more than one disease when conducting analytical observational studies could broaden the understanding of factors for those tropical and neglected diseases potentially endemic in this region.

The overall Leptospira seroprevalence estimated in the current study was $27.81 \%$, very similar to the report from San Juan, Puerto Rico $(27.2 \%, 55 / 202){ }^{25}$. Additional studies conducted in the Urabá region using a definition of seropositive outcome $\geq 1: 100$ titers by MAT, reported a Leptospira seroprevalence of $35.6 \%{ }^{14}$ and $12.5 \%{ }^{13}$. We also estimated an overall cumulative seroincidence of Leptospira of $14.60 \%$; to the best of our knowledge, this could be the first estimation of Leptospira seroincidence in Colombia, which helps to identify potential areas at risk of leptospires transmission.

367 The factors associated with both seroprevalent and seroincident cases of Leptospira infection, 368 after controlling for potentially confounding variables and adjusting for our design effect, were 369 history of outdoor occupation such as farming, agriculture, or daily laboring, and older age. For 370 the seroprevalence analysis, male gender was also a factor associated with Leptospira infection. 371 These exposures (outdoor labor) are recognized as an occupational risk for Leptospira infection 3723,26 . These results are confirmed by our demographic data, showing that male individuals over 15 373 years old have a high probability of working outdoors in the Urabá region. Furthermore, the risk 
medRxiv preprint doi: https://doi.org/10.1101/2021.10.23.21265419; this version posted October 26, 2021. The copyright holder for this preprint (which was not certified by peer review) is the author/funder, who has granted medRxiv a license to display the preprint in perpetuity. It is made available under a CC-BY-NC-ND 4.0 International license .

374 markers identified in our study, such as gender and age, were also reported as factors associated with Leptospira infection in previous studies ${ }^{6,27}$.

376

377

378

379

380

381

382

383

384

385

386

387

388

389

390

391

392

393

394

395

396

397

398

399

400

401

402

403

404

405

406

407

Other characteristics found in our study area, such as poverty and some cultural practices (e.g., an abundance of domestic animals and precariousness in household construction) are conditions highly associated with the presence of a large number of tropical zoonotic diseases ${ }^{28}$. Our analysis showed that the tenancy of piglets and the eyesight of opossums in the peridomiciliary area were important risk factors for seroprevalent cases, and the presence of a dirt floor inside households was associated with both seroprevalent and seroincident cases of Leptospira infection. Other studies have identified the presence of piglets and opossums in the peridomiciliary area as risk factors for Leptospira infection; these mammals have been considered as potential hosts participating in the life cycles of several Leptospira species ${ }^{3,29,30}$. Also, Bierke et al. ${ }^{31}$ found that Leptospira can survive for long periodsin several types of soil depending on its physical, chemical, and biological conditions such as $\mathrm{pH}$, temperature, or mineral concentration. Furthermore, a significant amount of Leptospira has been detected in $31 \%$ $(22 / 70)$ of samples from different soil microenvironments in a neighborhood endemic leptospirosis in Salvador, Bahia, Brazil ${ }^{32}$.

Leptospira infection in the Department of Antioquia is most commonly caused by serogroups of the L. interrogans species ${ }^{9}$. A study conducted in the Urabá region on patients with leptospirosis showed a high proportion of infection for L. interrogans serogroups of Copenhageni (28.6\%), Hardjo (20.6\%), Australis (17.5\%), Canicola (11.1\%), and Pomona (6.3\%). Other Leptospira serogroups were also found to have a high infection proportion, including Tarassovi (25.4\%), Grippotyphosa (17.5\%), Shermani (9.5\%), Ballum (7.9\%), Cynopteri (3.2\%), and Panama $(1.6 \%)^{28}$. Moreover, in the same study, of 199 patients with febrile syndrome, $11.56 \%$ were infected by L. interrogans serogroup Icterohaemorrhagiae, $10.05 \%$ were infected by Sejroe, and other serogroups registered a proportion of infection near to $10 \%{ }^{20}$. Regarding seroprevalent cases in the Urabá region, it was reported that $87 \%$ of seroprevalent cases had high titers against Icterohaemorrhagiae, followed by the Sejroe serogroup [14]. Likewise, in a study conducted in the city of Cali in the south of Colombia, the seroprevalence of Leptospira was $12.53 \%$, and the most frequent serogroup in seroprevalent cases was Australis $(61.4 \%$ of prevalent cases) [33]. 
medRxiv preprint doi: https://doi.org/10.1101/2021.10.23.21265419; this version posted October 26, 2021. The copyright holder for this preprint (which was not certified by peer review) is the author/funder, who has granted medRxiv a license to display the preprint in perpetuity. It is made available under a CC-BY-NC-ND 4.0 International license .

408 Although multinomial regression modeling is infrequently used to analyze infectious diseases ${ }^{33}$,

409 this method had the advantage of estimating the simultaneous effects of multiple factors. In our

410 study, we analyzed the factors associated with the risk of Leptospira infection, stratified in two

411 categories (L. interrogans serogroups and other species serogroups), and, according to our

412 knowledge, this is the first publication that reports its use in the study of Leptospira infection. In

413 this sense, outdoor occupations, age in years, male gender, the presence of dirt soil floors, and

414 the presence of piglets and opossums in peridomiciliary areas were factors associated with

415 seroprevalent cases of L. interrogans serogroups. Additionally, the presence of pit latrines

416 around households and turkeys as companionship were risk factors for seropositivity against

417 other Leptospira species serogroups. Similarly, a lack of toilets inside the households was a

418 factor associated with Leptospira seropositivity (OR unadjusted $=3.75 ; 95$ CI\%: 1.33-10.60) in

419 a study carried out in the south of Colombia ${ }^{34}$. Recently, a study in Germany identified the

420 presence of poultry in peridomiciliary areas as a risk factor for Leptospira infection ${ }^{26}$. However,

421 it is most likely that the presence of poultry or turkeys in peridomiciliary areas is associated with

422 the presence of synanthropic rodents or wild mammals, a necessary condition to maintain

423 leptospires in the environment ${ }^{35}$.

Regarding seroincidence cases, the multinomial analysis identified the presence of rodents in

426 intra or peridomiciliary areas, outdoor occupations, the presence of corn cultivation in

427 peridomiciliary areas (proxy of the presence of synanthropic and wild mammals), and age in

428 years as factors associated with seroincident cases of $L$. interrogans serogroups. In this

429 multinomial analysis, we also found that the presence of hunting canines and cassava cultivation

430 in peridomiciliary areas were risk factors for seroincident cases for other Leptospira species

431 serogroups. Similar to urban areas of Brazil, where only L. interrogans serogroup is circulating,

432 household conditions (household income), sociodemographic aspects (age, gender, and

433 occupation), and rat infestation were risk factors for Leptospira infection ${ }^{5,6,27}$. Regarding the

434 canines, these domestic animals have been considered important reservoirs or hosts in the

435 infection cycle of Leptospira because they can expel the leptospires through their urine for long

436 periods of time (weeks or months) ${ }^{36}$. Different serogroups of Leptospira such as Canicola,

437 Autumnalis, Australis, Grippotyphosa, Harjo, Pomona, Pyrogenes, and Djasiman, among others

$4383^{37-40}$, have been found in canines. In Brazil, a longitudinal study of dogs found a seroprevalence

439 between $9.3 \%$ (95\% CI:6.7-12.6) and 19\% (95\% CI:14.1-25.2) in different periods.

440 Additionally, an overall cumulative seroincidence of 11\% (95\%CI:9.1-13.2) was estimated, and 
medRxiv preprint doi: https://doi.org/10.1101/2021.10.23.21265419; this version posted October 26, 2021. The copyright holder for this preprint (which was not certified by peer review) is the author/funder, who has granted medRxiv a license to display the preprint in perpetuity. It is made available under a CC-BY-NC-ND 4.0 International license .

441 the cumulative seroincidence by trimester varied between 6\% (95\% CI:3.3-10.6) and 15.3\%

444 In this study, reactivity to Bataviae was the most frequent among prevalent and incident cases of infected rodents or canines ${ }^{41,42}$. Nevertheless, detection of antibodies against Djasiman and

447 Icterohaemorrhagiae serogroups evidenced additional exposure to sources contaminated with 448 leptospires shed by synanthropic or wild mammals ${ }^{3,29}$. Regarding different species of $L$. interrogans serogroups, this study showed a high frequency of seroprevalent and seroincident cases against the Tarassovi serogroup, which is mainly found in pigs ${ }^{3,30}$. Even though the

451 Tarassovi serogroup is present in different species of Leptospira considered as pathogens and

452 classified into subgroup II, this serogroup has not been incriminated in clinical cases of

453 leptospirosis in humans yet ${ }^{43}$. The Panama serogroup was another important serogroup found in 454 seroprevalent and seroincident cases. This serogroup was initially described in opossums, wild 455 rodents, and numerous domestic animals. However, there are several clinical cases of 456 leptospirosis described in humans, potentially caused by the Panama serogroup ${ }^{44,45}$. Finally, 457 reactivity to the Cynopteri serogroup was the third in seroprevalent cases and the fourth in 458 seroincident cases. This serogroup is frequent in bats and various wild animals ${ }^{3,46,47}$.

460 The main limitation of this study was the moderate sampling coverage of individuals (58.41\%).

461 Some participants declined the study enrollment, and others moved out in search of a job.

462 Consequently, selection bias was likely present in this study at the analysis unit (inhabitants of

463 households). Another important limitation was the information bias as a result of obtaining group

464 information of participants enrolled in each household through the family head, such as cultural

465 practices shared by all household inhabitants. However, this study considered that some habits

466 and perceptions are widespread in households depending on the region or area where people

467 have grown or lived; for instance, the risk perceptions related to infectious diseases, self-care

468 measures, or land use. For the seroincidence analysis, the main limitation was the losses to

469 follow-up. Selection bias was likely introduced in the estimation of the overall cumulative

470 seroincidence, serogroups seroincidence, and associated factors because the majority of the

471 losses were males. Another potential limitation was the sensitivity and specificity of the

472 microagglutination test to detect the seroincident and seroprevalent cases, especially in

473 seropositive individuals who had titers equal to 1:50. Nevertheless, the sensitivity and specificity

474 of the test could be increased when diverse serovars are included, especially those circulating in 
medRxiv preprint doi: https://doi.org/10.1101/2021.10.23.21265419; this version posted October 26, 2021. The copyright holder for this preprint (which was not certified by peer review) is the author/funder, who has granted medRxiv a license to display the preprint in perpetuity. It is made available under a CC-BY-NC-ND 4.0 International license .

475 the same area. In this study, 32 Leptospira strains representing several species and serogroups

476 (Table 1) were included, and a random selection of $20 \%$ of the total human serum samples

477 collected at T0 was used to select the final panel of 16 Leptospira strains tested in this study. In

478 addition, the classification of most probable infecting serogroup (L. interrogans and other

479 Leptospira species serogroups) by MAT is not perfect and it could result in misclassification

480 bias. Finally, information biases are also a concern in the followed-up participants, specifically,

481 memory biases respecting changing exposures such as episodes of fever, sporadic outdoor

482 occupations, and contact with synanthropic, wild, or domestic mammals, among other variables.

\section{CONCLUSIONS}

The current study aimed to understand the potential public health problem of Leptospira transmission in the rural areas of Urabá, Colombia, where fatal cases of leptospirosis have occurred. The estimated Leptospira seroprevalence was $27.81 \%$, with infections being predominantly caused by serogroups of $L$. interrogans $(65.66 \%)$. The overall seroincidence of Leptospira was $14.60 \%$, and a contrast between seroprevalence results with a very similar distribution between L. interrogans and other Leptospira species serogroups was evident. Also, we identified important risk factors for Leptospira infection, which indicates that although different activities and characteristics are related to different species of Leptospira, there is a major risk of infection caused by different species circulating in the area. The sequential binary and multinomial regression analysis of this study allowed us to obtain the estimated risk and protective factors associated with Leptospira infection (seroprevalent and seroincident cases) in rural areas of the Urabá region. The characteristics of the cases of Leptospira infection identified in this study agreed with the cases reported in the Colombian surveillance system for Leptospira 48. Also, this rural area seems to have different species of Leptospira circulating, from other areas such as Salvador Bahia, Brazil, which is more urban area and where the rat has a major role in transmission. But this study is consistent with other works showing that transmission in rural areas is also dependent on wild animals and environmental conditions favoring the risk of infection, making disease control difficult and highlights the importance of this study, which identify factors associated to Leptospira infection. The longterm goal of this work is to strengthen the surveillance system by identifying areas at risk for Leptospira transmission. This, in turn, will aid targeted efforts to provide appropriate diagnosis and timely treatment and ultimately reduce the case fatality rate associated with the disease. Finally, this study will help to prioritize and develop strategies to prevent incident cases in this area and will help to strengthen 
medRxiv preprint doi: https://doi.org/10.1101/2021.10.23.21265419; this version posted October 26, 2021. The copyright holder for this preprint (which was not certified by peer review) is the author/funder, who has granted medRxiv a license to display the preprint in perpetuity.

It is made available under a CC-BY-NC-ND 4.0 International license .

509 educational strategies to prevent the transmission of the disease in the communities from rural

510 areas of Colombia.

\section{ACKNOWLEDGEMENTS}

514 We are thankful to the research groups Salud y Ambiente and Epidemiología of Facultad

515 Nacional de Salud Pública from Universidad de Antioquia and the Laboratory of Epidemiology

516 of Microbial Diseases from Yale School of Public Health for their logistic support to conduct

517 this study. We also recognize the help from the communities of Alto de Mulatos and Las

518 Changas from the Urabá region. We express our gratitude to the Fogarty International Center for 519 the help and advice obtained through the Research Training Program on the Impact of Zoonotic 520 and Vector-borne Viruses, Rickettsiae, and Leptospira in Acute Undifferentiated Febrile 521 Illnesses (5D43TW010331-05), NIH through the Naturally Acquired and Vaccine-Mediated 522 Immunity to Leptospirosis grant (R01AI121207), and Departamento Administrativo de Ciencia, 523 Tecnología e Innovación (Colciencias) (award: 111565741009). The funders had no role in the 524 study design, data collection and analysis, decision to publish, or preparation of the manuscript.

CONFLICT OF INTEREST

528 None.

529

\section{References}

532 1. Ko AI, Goarant C, Picardeau M. Leptospira: The dawn of the molecular genetics era for 533 an emerging zoonotic pathogen. Nat Rev Microbiol. 2009;7(10):736-747.

534 doi:10.1038/nrmicro2208

535 2. Thibeaux R, Girault D, Bierque E, et al. Biodiversity of environmental Leptospira:

536 Improving identification and revisiting the diagnosis. Front Microbiol. 2018;9(MAY):1-

537 14. doi:10.3389/fmicb.2018.00816

538 3. Bharti AR, Nally JE, Ricaldi JN, et al. Leptospirosis: a zoonotic disease of global 539 importance. Lancet Infect Dis. 2003;3(December):757-771.

540 4. Costa F, Hagan JE, Calcagno J, et al. Global Morbidity and Mortality of Leptospirosis : A Systematic Review. PLoS Negl Trop Dis. 2015;17(9):e0003898. 
medRxiv preprint doi: https://doi.org/10.1101/2021.10.23.21265419; this version posted October 26, 2021. The copyright holder for this preprint (which was not certified by peer review) is the author/funder, who has granted medRxiv a license to display the preprint in perpetuity. It is made available under a CC-BY-NC-ND 4.0 International license .

543 5. Hagan JE, Moraga P, Costa F, et al. Spatiotemporal Determinants of Urban Leptospirosis Transmission: Four-Year Prospective Cohort Study of Slum Residents in Brazil. PLoS Negl Trop Dis. 2016;10(1):1-16. doi:10.1371/journal.pntd.0004275

546 6. Felzemburgh RDM, Ribeiro GS, Costa F, et al. Prospective Study of Leptospirosis Transmission in an Urban Slum Community: Role of Poor Environment in Repeated

7. Plowright RK, Parrish CR, McCallum H, et al. Pathways to zoonotic spillover. Nat Rev Exposures to the Leptospira Agent. PLoS Negl Trop Dis. 2014;8(5).

8. Hacker KP, Sacramento GA, Cruz JS, et al. Influence of rainfall on leptospira infection and disease in a tropical urban setting, Brazil. Emerg Infect Dis. 2020;26(2):311-314. doi:10.3201/eid2602.190102

9. Bello S, Rodríguez M, Paredes A, et al. Comportamiento de la vigilancia epidemiológica de la leptospirosis humana en Colo. Biomedica. 2013;33.

10. Instituto Nacional de Salud. Informe final del evento leptospirosis. Published online 2018:1-3.

11. Instituto Nacional de Salud. Informe final del evento leptospirosis. Published online 2016:1-19.

12. Instituto Nacional de Salud. Informe final del evento leptospirosis. Published online 2017:1-3.

13. Piedad A-F, Jaramillo R-BN, Arboleda N-M. Situación de la leptospirosis en el Urabá antioqueño colombiano: estudio seroepidemiológico y factores de riesgo en población general urbana. Cad Saude Publica. 2007;23(9):2094-2102. doi:10.1590/S0102311X2007000900017

14. Padmanabha H, Hidalgo M, Valbuena G, et al. Geographic variation in risk factors for SFG rickettsial and leptospiral exposure in Colombia. Vector-Borne Zoonotic Dis. 2009;9(5):483-490. doi:10.1089/vbz.2008.0092

15. Arroyave E, Londoño AFAF, Quintero JCC, et al. Etiología y caracterización epidemiológica del síndrome febril no palúdico en tres municipios del Urabá antioqueño,

574 16. Pérez-García J, Arboleda M, Agudelo-Flórez P. Leptospirosis infantil en pacientes con síndrome febril en la región de Urabá, Colombia. Rev Peru Med Exp Salud Publica. 
medRxiv preprint doi: https://doi.org/10.1101/2021.10.23.21265419; this version posted October 26, 2021. The copyright holder for this preprint (which was not certified by peer review) is the author/funder, who has granted medRxiv a license to display the preprint in perpetuity. It is made available under a CC-BY-NC-ND 4.0 International license .

577 17. Agudelo-Flórez P, Londoño AF, Quiroz VH, et al. Prevalence of Leptospira spp . in Urban Rodents from a Groceries Trade Center of Medellín, Colombia. Am J Trop Med Hyg. 2009;81(5):906-910. doi:10.4269/ajtmh.2009.09-0195

18. Romero MH., Sánchez JA., Hayek LC. The prevalence of antibodies against Leptospira in urban human and canine populations from the Tolima department [Prevalencia de anticuerpos contra Leptospira en población urbana humana y canina del Departamento del Tolima]. Rev Salud Publica. 2010;12(2):268-275.

19. Trimble A, Blevins CA, Beard LA, Deforno AR, Davis EG. Seroprevalence, frequency of leptospiuria , and associated risk factors in horses in Kansas, Missouri , and Nebraska from 2016- 2017. PLoS One. 2018;13(10):1-12.

20. Pérez-García J, Agudelo-Flórez P, Parra-Henao G, Ochoa J, Arboleda M. Incidencia y subregistro de leptospirosis comparando tres métodos diagnósticos, en una región endémica, Urabá, Colombia. Biomedica. 2019;39(1):7-11.

21. Quintero JC, Paternina LE, Uribe Y A, et al. Eco-epidemiological analysis of rickettsial seropositivity in rural areas of Colombia: A multilevel approach. PLoS Negl Trop Dis. 2017;18:1-19.

22. Localio AR, Margolis DJ, Berlin JA. Relative risks and confidence intervals were easily computed indirectly from multivariable logistic regression. J Clin Epidemiol. 2007;60(9):874-882. doi:10.1016/j.jclinepi.2006.12.001

23. Quintero Vélez JC, Faccini-Martínez ÁA, Rodas González JD, et al. Fatal Rickettsia rickettsii infection in a child, Northwestern Colombia, 2017. Ticks Tick Borne Dis. 2019;10(Aug):995-996. doi:10.1016/j.ttbdis.2019.05.009

24. Restrepo B, Rodas JD, Montoya-Ruiz C, Zuluaga AM, Parra-Henao G, Agudelo-Flórez P. Evidencia serológica retrospectiva de infecciones por Leptospira spp., dengue, hantavirus y arenavirus en indígenas Emberá-Katío, Colombia. Rev Chil infectología. 2016;33(4):472-473. doi:10.4067/s0716-10182016000400015

26. Brockmann SO, Ulrich L, Piechotowski I, et al. Risk factors for human Leptospira seropositivity in South Germany. Springerplus. 2016;5(1). doi:10.1186/s40064-016-34838

27. Maciel EAP, de Carvalho ALF, Nascimento SF, et al. Household transmission of 
medRxiv preprint doi: https://doi.org/10.1101/2021.10.23.21265419; this version posted October 26, 2021. The copyright holder for this preprint (which was not certified by peer review) is the author/funder, who has granted medRxiv a license to display the preprint in perpetuity. It is made available under a CC-BY-NC-ND 4.0 International license .

611

612

613

614

615

616

617

618

619

620

621

622

623

624

625

626

627

628

629

630

631

632

633

634

635

636

637

638

639

640

641

642

643

644

doi:10.1371/journal.pntd.0000154

28. Yusti D, Arboleda M, Agudelo-Flórez P. Factores de riesgo sociales y ambientales relacionados con casos de leptospirosis de manejo ambulatorio y hospitalario, Turbo, Colombia. Biomedica. 2013;33(SUPPL.1):117-129. doi:10.7705/biomedica.v33i0.1457

29. Fornazari F, Langoni H, Marson PM, Nóbrega DB, Teixeira CR. Leptospira reservoirs among wildlife in Brazil: Beyond rodents. Acta Trop. 2018;178:205-212. doi:10.1016/j.actatropica.2017.11.019

30. Cruz-Romero A, Alvarado-Esquivel C, Romero-Salas D, et al. Seroepidemiology of Leptospira infection in backyard pigs in Durango State, Mexico . Eur J Microbiol Immunol. 2018;8(July):1-4. doi:10.1556/1886.2018.00009

31. Bierque E, Thibeaux R, Girault D, Soupé-Gilbert ME, Goarant C. A systematic review of Leptospira in water and soil environments. PLoS One. 2020;15(1):1-22.

doi:10.1371/journal.pone.0227055

32. Schneider AG, Casanovas-Massana A, Hacker KP, et al. Quantification of pathogenic Leptospira in the soils of a Brazilian urban slum. PLoS Negl Trop Dis. 2018;12(4):1-15. doi:10.1371/journal.pntd.0006415

33. Varga C, Middleton D, Walton R, et al. Evaluating risk factors for endemic human Salmonella Enteritidis infections with different phage types in Ontario, Canada using multinomial logistic regression and a case-case study approach. BMC Public Health. 2012;12(1):1. doi:10.1186/1471-2458-12-866

34. Escandón-Vargas K, Osorio L, Astudillo-Hernández M. Seroprevalence and factors associated with Leptospira infection in an urban district of Cali, Colombia. Cad Saude Publica. 2017;33(5):e00039216. doi:10.1590/0102-311X00039216

35. Barragan V, Nieto N, Keim P, Pearson T. Meta-analysis to estimate the load of Leptospira excreted in urine: Beyond rats as important sources of transmission in low-income rural communities. BMC Res Notes. 2017;10(1):1-7. doi:10.1186/s13104-017-2384-4

36. Rojas P, Monahan AM, Schuller S, Miller IS, Markey BK, Nally JE. Detection and quantification of leptospires in urine of dogs: A maintenance host for the zoonotic disease leptospirosis. Eur J Clin Microbiol Infect Dis. 2010;29(10):1305-1309.

doi:10.1007/s10096-010-0991-2

37. Stokes JE, Kaneene JB, Schall WD, et al. Prevalence of serum antibodies against six Leptospira serovars in healthy dogs. J Am Vet Med Assoc. 2007;230(11):1657-1664. doi:10.2460/javma.230.11.1657

38. Miller RI, Ross SP, Sullivan ND, Perkins NR. Clinical and epidemiological features of 
medRxiv preprint doi: https://doi.org/10.1101/2021.10.23.21265419; this version posted October 26, 2021. The copyright holder for this preprint (which was not certified by peer review) is the author/funder, who has granted medRxiv a license to display the preprint in perpetuity. It is made available under a CC-BY-NC-ND 4.0 International license .

645

646

647

648

649

650

651

652

653

654

655

656

657

658

659

660

661

662

663

664

665

666

667

668

669

670

671

672

673

674

675

676

677

678

canine leptospirosis in North Queensland. Aust Vet J. 2007;85(1-2):13-19.

doi:10.1111/j.1751-0813.2006.00089.x

39. Alton GD, Berke O, Reid-Smith R, Ojkic D, Prescott JF. Increase in seroprevalence of canine leptospirosis and its risk factors, Ontario 1998-2006. Can J Vet Res. 2009;73(3):167-175.

40. Morikawa VM, Bier D, Pellizzaro M, et al. Seroprevalence and seroincidence of Leptospira infection in dogs during a one-year period in an endemic urban area in Southern Brazil. Rev Soc Bras Med Trop. 2015;48(1):50-55. doi:10.1590/0037-86820213-2014

41. Benacer D, Mohd Zain SN, Sim SZ, et al. Determination of Leptospira borgpetersenii serovar Javanica and Leptospira interrogans serovar Bataviae as the persistent Leptospira serovars circulating in the urban rat populations in Peninsular Malaysia. Parasites and Vectors. 2016;9(1):1-11. doi:10.1186/s13071-016-1400-1

42. Boonciew P, Kurilung A, Altheimer K, Hartmann K, Prapasarakul N. Draft Genome Sequence of Leptospira interrogans Serovar Bataviae Strain D64, Isolated from the Urine of an Asymptomatic Dog in Pathum Thani, Thailand. Microbiol Resour Announc. 2020;9(30):e00361. doi:10.1128/MRA.00361-20

43. Picardeau M. Virulence of the zoonotic agent of leptospirosis: Still terra incognita? Nat Rev Microbiol. 2017;15(5):297-307. doi:10.1038/nrmicro.2017.5

44. Vado-Solís I, Cárdenas-Marrufo MF, Jiménez-Delgadillo B, et al. Clinicalepidemiological study of leptospirosis in humans and reservoirs in Yucatán, México. Rev Inst Med Trop Sao Paulo. 2002;44(6):335-340. doi:10.1590/S0036-46652002000600008

45. Martins G, Loureiro AP, Hamond C, et al. First isolation of Leptospira noguchii serogroups Panama and Autumnalis from cattle. Epidemiol Infect. 2015;143(7):15381541. doi:10.1017/S0950268814002416

46. Lins ZC, Lopes ML. Isolation of Leptospira from wild forest animals in Amazonian Brazil. Trans R Soc Trop Med Hyg. 1984;78(1):124-126. doi:10.1016/00359203(84)90191-3

47. Langoni H, Kuribara IY, Ferreira Lopes Correa AP, Ullmann LS, Sánchez GP, Lucheis SB. Anti-leptospirosis agglutinins in Brazilian capybaras (hydrochoerus hydrochaeris). $J$ Venom Anim Toxins Incl Trop Dis. 2016;22(1):13-16. doi:10.1186/s40409-016-0059-6 48. Instituto Nacional de Salud (INS). Boletín Epidemiológico Semana: Leptospirosis.; 2020. 49. Costa F, Ribeiro GS, Felzemburgh RDM, et al. Influence of Household Rat Infestation on Leptospira Transmission in the Urban Slum Environment. PLoS Negl Trop Dis. 
medRxiv preprint doi: https://doi.org/10.1101/2021.10.23.21265419; this version posted October 26, 2021. The copyright holder for this preprint (which was not certified by peer review) is the author/funder, who has granted medRxiv a license to display the preprint in perpetuity. It is made available under a CC-BY-NC-ND 4.0 International license.

679 2014;8(12). doi:10.1371/journal.pntd.0003338

680

681

682 Figure 1. Map of the study area localized in rural areas of Urabá region of Antioquia, Colombia. 683

684 Figure 2. Frequency of L. interrogans and other Leptospira serogroups in the seroprevalent 685 cases.

686

687 Figure 3. Frequency of L. interrogans and other Leptospira serogroups in the seroincident cases. 688 
Table 1. Panel of Leptospira strains used in this study for the microagglutination test (MAT)

\begin{tabular}{|c|c|c|c|}
\hline Species & Serogroup & Serovar* & Strain \\
\hline L. interrogans & Djasiman & Djasiman $^{*}$ & Djasiman \\
\hline L. interrogans & Icterohaemorrhagiae & Icterohaemorrhagiae & RGA \\
\hline L. interrogans & Icterohaemorrhagiae & Copenhageni & M 20 \\
\hline L. interrogans & Icterohaemorrhagiae & Copenhageni $^{*}$ & L1 130 \\
\hline L. interrogans & Sejroe & Hardjo & Hardjoprajitno \\
\hline L. interrogans & Sejroe & Wolffi & 3705 \\
\hline L. interrogans & Bataviae & Bataviae* $^{*}$ & Van Tienen \\
\hline L. interrogans & Pyrogenes & Pyrogenes* & Salinem \\
\hline L. interrogans & Pyrogenes & Manilae* & L495 \\
\hline L. interrogans & Pomona & Pomona* & Pomona \\
\hline L. interrogans & Autumnalis & Autumnalis* & Akiyami A \\
\hline L. interrogans & Canicola & Canicola* $^{*}$ & H. Ultrecht IV \\
\hline L. interrogans & Hebdomadis & Hebdomadis & Hebdomadis \\
\hline L. interrogans & Australis & Bratislava $^{*}$ & Jez Bratislava \\
\hline L. noguchii & Louisiana & Louisiana & LSU 1945 \\
\hline L. noguchii & Panama & Panama* & CZ 214 K \\
\hline L. borgpetersenii & Tarassovi & Tarassovi* $^{*}$ & Perepelitsin \\
\hline L. borgpetersenii & Ballum & Castellonis & Castellon 3 \\
\hline L. borgpetersenii & Ballum & Ballum & Mus 127 \\
\hline L. borgpetersenii & Mini & Mini* & Sari \\
\hline L. weilii & Celledoni & Celledoni & Celledoni \\
\hline L. weilii & Javanica & Coxi & Cox \\
\hline L. kirschneri & Cynopteri & Cynopteri* & $3522 \mathrm{C}$ \\
\hline L. kirschneri & Grippotyphosa & Grippotyphosa* & Duyster \\
\hline L. santarosai & Shermani & Shermani & $1342 \mathrm{~K}$ \\
\hline L. santarosai & Tarassovi & ND $^{*}$ & AIM \\
\hline L. santarosai & Tarassovi & ND & JET \\
\hline L. alexanderi & Manhao & Manhao 3 & L 60T \\
\hline L. alstoni & Ranarum & Pingchang & $80-412 \mathrm{~T}$ \\
\hline L. kmetyi & Tarassovi & Malaysia* $^{*}$ & Bejo-Iso9 \\
\hline L. mayottensis & ND & $\mathrm{ND}$ & 200901122 \\
\hline L. biflexa & Semaranga & Patoc & Patoc 1 \\
\hline
\end{tabular}

*Final selection of strains used for MAT evaluation of all human serum samples 
medRxiv preprint doi: https://doi.org/10.1101/2021.10.23.21265419; this version posted October 26, 2021. The copyright holder for this preprint (which was not certified by peer review) is the author/funder, who has granted medRxiv a license to display the preprint in perpetuity.

It is made available under a CC-BY-NC-ND 4.0 International license.

Table 2. Multivariate analysis of seroprevalent cases of Leptospira among different serogroups (mixedeffects multinomial logistic regression model)

\begin{tabular}{|c|c|c|}
\hline Variables & L. interrogans serogroup & $\begin{array}{l}\text { Others Leptospira } \\
\text { species serogroups }\end{array}$ \\
\hline & $\mathrm{OR}_{\text {adjust }}(95 \% \mathrm{CI})$ & $\mathrm{OR}_{\text {adjust }}(95 \% \mathrm{CI})^{\mathrm{a}}$ \\
\hline \multicolumn{3}{|l|}{ Individuals } \\
\hline Outdoor occupation & $2.06(1.31-3.26)$ & \\
\hline Male gender & $2.34(1.55-3.53)$ & \\
\hline Age, years (1-15) & 1.00 & \\
\hline Age, years (>15-29) & $2.52(1.44-4.41)$ & \\
\hline Age, years (>29-46) & $1.72(0.94-3.13)$ & \\
\hline Age, years $(>46)$ & $1.95(1.07-3.55)$ & \\
\hline \multicolumn{3}{|l|}{ Household characteristics } \\
\hline \multicolumn{3}{|l|}{ Floor material } \\
\hline Dirt soil & $1.87(1.21-2.89)$ & \\
\hline \multicolumn{3}{|l|}{$\begin{array}{c}\text { Public services in } \\
\text { household }\end{array}$} \\
\hline Presence of pit latrine & & $2.34(1.27-4.32)$ \\
\hline \multicolumn{3}{|l|}{$\begin{array}{l}\text { Presence of wild animals } \\
\text { in peri domiciliary area }\end{array}$} \\
\hline Opossum & $1.58(1.11-2.23)$ & \\
\hline \multicolumn{3}{|l|}{$\begin{array}{c}\text { Animal husbandry } \\
\text { purpose }\end{array}$} \\
\hline Porcine (piglet) & $1.66(1.11-2.49)$ & \\
\hline Turkeys (companionship) & & $4.99(2.03-12.30)$ \\
\hline
\end{tabular}

${ }^{a}$ Adjusted by age, gender and outdoor occupation 
medRxiv preprint doi: https://doi.org/10.1101/2021.10.23.21265419; this version posted October 26, 2021. The copyright holder for this preprint (which was not certified by peer review) is the author/funder, who has granted medRxiv a license to display the preprint in perpetuity.

\section{It is made available under a CC-BY-NC-ND 4.0 International license .}

Table 3. Multivariate analysis of seroincident cases of Leptospira among different serogroups (mixedeffects multinomial logistic regression model)

\begin{tabular}{|c|c|c|}
\hline Variables & L. interrogans serogroup & $\begin{array}{l}\text { Others Leptospira } \\
\text { species serogroups }\end{array}$ \\
\hline & $\mathbf{R R}_{\text {adjust }}(95 \% \mathrm{CI})^{\mathrm{a}}$ & $\mathbf{R R}_{\text {adjust }}(95 \% \mathrm{CI})^{\mathbf{b}}$ \\
\hline \multicolumn{3}{|l|}{ Individuals } \\
\hline Outdoor occupation & $2.93(1.36-6.16)$ & \\
\hline Age (years) & $1.02(1.01-1.04)$ & \\
\hline \multicolumn{3}{|l|}{$\begin{array}{c}\text { Peri domiciliary area } \\
\text { characteristics }\end{array}$} \\
\hline \multicolumn{3}{|l|}{ Vegetation } \\
\hline Corn culture & $22.74(5.75-51.74)$ & \\
\hline Cassava culture & & $3.05(1.24-6.52)$ \\
\hline \multicolumn{3}{|c|}{ Synanthropic mammals } \\
\hline Rats & $2.81(1.07-7.12)$ & \\
\hline \multicolumn{3}{|l|}{$\begin{array}{c}\text { Animal husbandry } \\
\text { purpose }\end{array}$} \\
\hline Hunting canines & & $6.17(2.72-10.99)$ \\
\hline
\end{tabular}

${ }^{a}$ Adjusted by gender

${ }^{\mathrm{b}}$ Adjusted by age, gender and outdoor occupation 


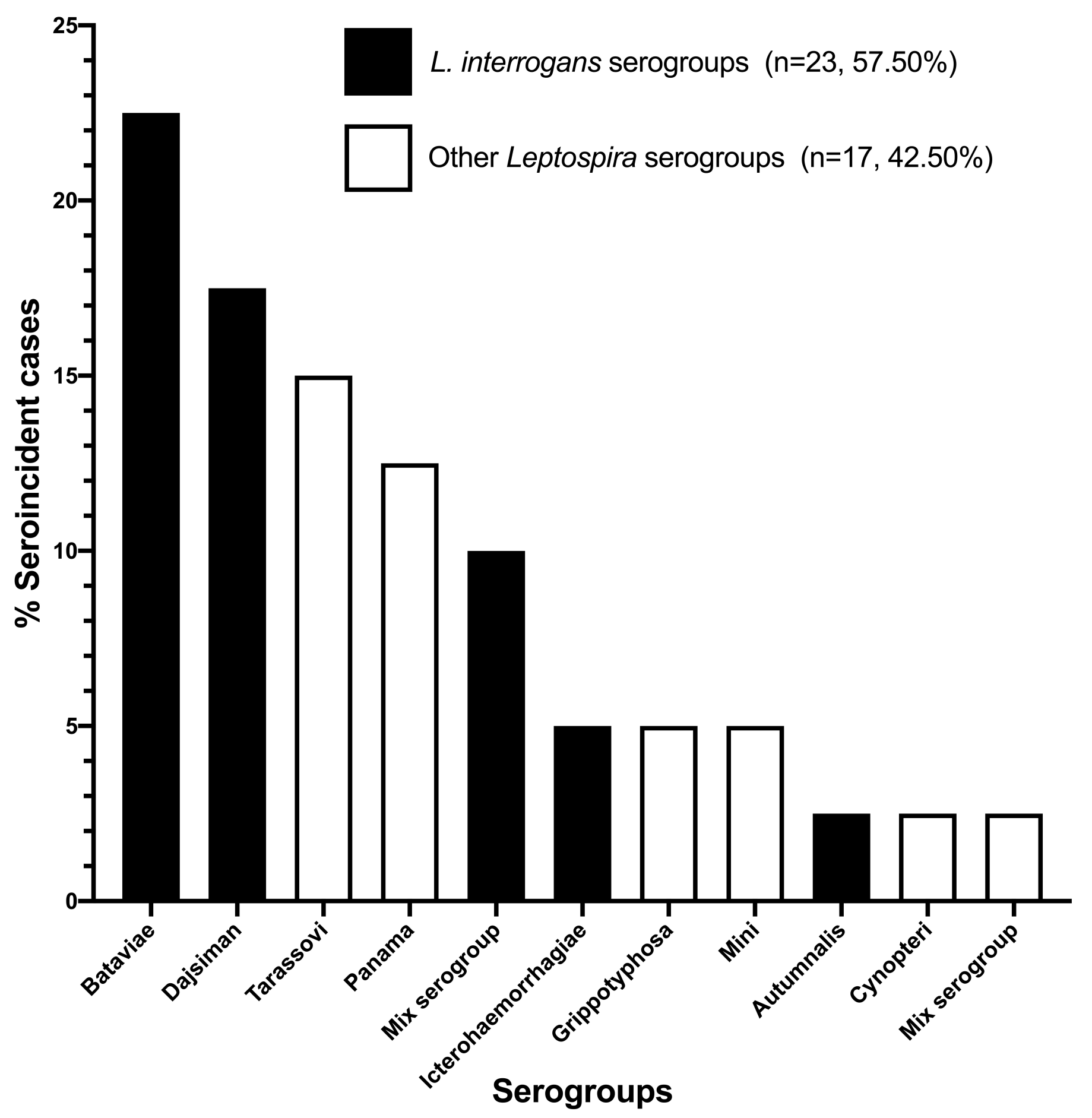




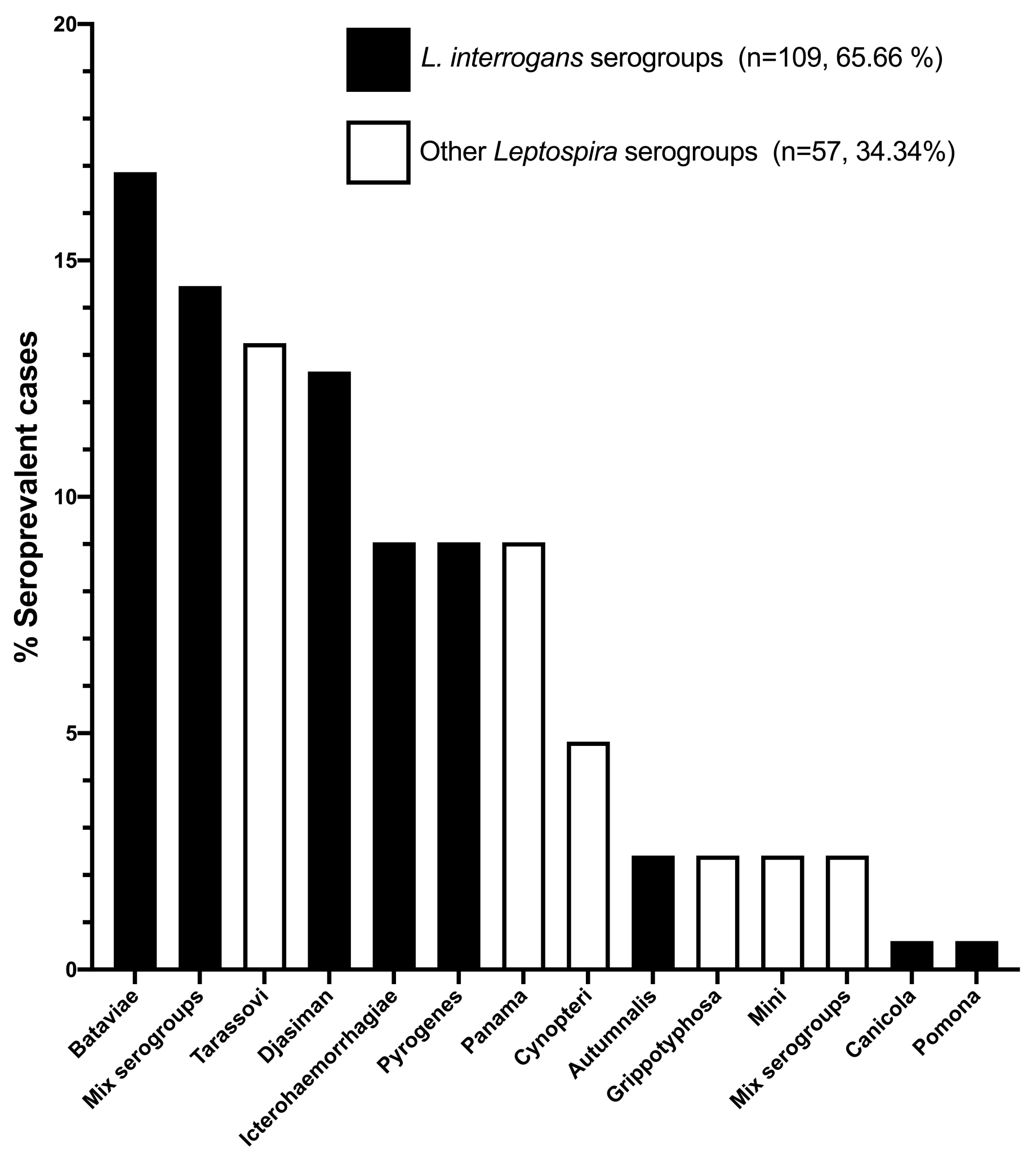

Serogroups 
